\title{
Asymptomatic carriage of plasmid-mediated multidrug- resistant Staphylococcus aureus in nasal tracts of persons in a semi-urban area of Nigeria
}

\author{
Jonathan Osariemen Isibor, Ehima Otabor \\ Department of Microbiology, Faculty of Natural Sciences, Ambrose Alli University, Ekpoma, Edo State, Nigeria
}

Email address:

joe_isibor@yahoo.com (Isibor J. O.)

\section{To cite this article:}

Jonathan Osariemen Isibor, Ehima Otabor. Asymptomatic Carriage of Plasmid-Mediated Multidrug-Resistant Staphylococcus aureus in Nasal Tracts of Persons in a Semi-Urban Area of Nigeria. American Journal of Life Sciences. Vol. 2, No. 4, 2014 , pp. $200-204$.

doi: $10.11648 /$ j.ajls.20140204.12

\begin{abstract}
Staphylococcus aureus remains one of the most important opportunistic bacterial pathogens of man and strains resistant to available drug classes have become more and more prevalent in clinical and community settings. The aim of this study was to determine the nasal carriage rates of multidrug - resistant (MDR) Staph aureus in food vendors and hospital workers in Ekpoma, Nigeria, and to assess whether resistance was plasmid - mediated. With the use of sterile swab sticks (Sterilin, UK), one hundred nasal swabs were obtained from consenting volunteers. Each swab was streaked on mannitol salt agar (Difco, Detroit MI) and incubated at $37^{\circ} \mathrm{C}$ for $24 \mathrm{hrs}$. Colonies growing on medium were Gram - stained and tested for catalase, coagulase and mannitol fermentation. Antibiotic susceptibility tests were performed using the Kirby-Bauer disc diffusion technique, and results were interpreted using the Clinical and Laboratory Standard Institute's guidelines. Results showed that 32 (32\%) of the 100 specimens screened yielded Staph aureus, with 18 (36\%) and $14(28 \%)$ of the isolates recovered from hospital workers and food vendors, respectively. The prevalence rate in males (40\%) compared with females (24\%) was not statistically significant ( $>0.05)$, using Student's t-test analysis. All the Staph aureus isolates were susceptible to Augmentin. The highest resistance rates of $65.6 \%, 59.3 \%$ and $50.0 \%$ were recorded for Amoxycillin, Ofloxacin and Oxacillin respectively, while low resistance rates were recorded for Gentamicin (9.38\%) and Cefuroxime (15.6\%). Of the 17 (53\%) MDR isolates of Staph aureus, only 4 (23.5\%) remained MDR after curing with $0.1 \mathrm{mg} / \mathrm{ml}$ acridine orange solution. Observance of personal hygiene can reduce the level of contamination or infection of carriers thereby reducing the risk of infection for others in the community, while rational use of antibiotics by health professionals and end users could help to curb the rising trend of antibiotic resistance within the community.
\end{abstract}

Keywords: Asymptomatic Carriage, Nasal Tract, Multidrug Resistance, Staphylococcus aureus, Plasmids, Ekpoma

\section{Introduction}

Staphylococcus species are among the most disease causing bacteria and a leading cause of community and hospital acquired bacterial infections [1], ranging from minor skin lesions such as boils and furuncles, to severe life threatening, infections such as pneumonia and urinary tract infections and also deep seated infections such as osteomyelitis and endocarditis [2]. Its pathogenic potential involves two mechanisms - tissue invasion and toxin production.

Staph aureus colonizes various anatomical sites of the average healthy person including the nares, skin, vagina and gastrointestinal tract [1], and in particular, nasal carriage of the organism has been reported to be linked to most community and hospital associated infections [3-7].

Contaminated surfaces and hands can contribute to the transmission of Staph aureus to the anterior nares; the latter serving as endogenous reservoirs from where clinical infections can occur within the colonized individual as well as within the community $[8,9]$.

The development of antibiotic resistance by strains of Staph aureus has risen to an embarrassing proportion in medical care facilities just as multidrug resistant (MDR) strains of the organism have been reported with increasing frequency worldwide [10]. Staph aureus has a remarkable capability of evolving different mechanisms of resistance to most antimicrobial agents [11] including the acquisition 
and transfer of resistance plasmids [12], a mutation in Staph aureus ribosomal RNA, a feature displayed in resistance to Linezolid [13]. The organism is also able to abrogate the effects of penicillin by destroying the $\beta$ lactam ring of the penicillin structure using $\beta$ - lactamase enzyme.

The persistence and carriage of this pathogen within the community, especially among asymptomatic persons, if not checked, could lead to untoward medical consequences as nasal spread of organisms have been known to play a vital role in epidemics. The present study was therefore aimed at determining the relative nasal carriage rates of MDR Staph aureus by two groups of persons and the level of plasmid involvement in the resistance pattern.

\section{Materials and Methods}

\subsection{Subjects Enrolled}

One hundred (100) nasal specimens were aseptically collected from 100 asymptomatic persons, within Ekpoma and its environs. These comprised of 50 food vendors and 50 hospital workers (doctors, laboratory staff and nurses), aged 18 to 35 years.

\subsection{Ethical Consideration}

Ethical approval was obtained from the Medical Directors of the hospitals whose staff participated in this study. Also, all participants gave their consent after being informed about the rationale of the study.

\subsection{Inclusion Criteria}

Persons of both sexes who had not been on any antibiotic treatment for the preceding two weeks before sampling, and who had not been hospitalized for the previous six months, were included in the study.

\subsection{Sampling and Culture}

Sterile swabs (Sterilin, UK) were moistened with sterile saline and used to swab both anterior nares of each person, properly labeled and taken to the Microbiology Laboratory of Irrua Specialist Teaching Hospital, Irrua. Each swab was streaked on mannitol salt agar (Difco, Detroit MI). Plates were incubated at $37^{\circ} \mathrm{C}$ for $24 \mathrm{hrs}$, while those without distinct colonial growth were incubated for a further $24 \mathrm{hrs}$.

\subsection{Identification of Isolates}

Colonies growing on agar were Gram-stained and those showing as Gram-positive cocci were tested for catalase and coagulase enzymes and mannitol fermentation. Bacterial colonies confirmed as Staph aureus were streaked on nutrient agar slants and stored in a refrigerator until required for further tests.

\subsection{Antibiotic Susceptibility Testing}

Susceptibility to antibiotics was assessed using the
Kirby-Bauer disc diffusion technique while results were read following the Clinical Laboratory Standards Institute's guidelines [14]. The panel of antibiotics used included Amoxicillin $(25 \mu \mathrm{g})$, Augmentin $(30 \mu \mathrm{g})$, Ceftazidime $(30 \mu \mathrm{g})$, Cefuroxime $(30 \mu \mathrm{g})$, Oxacillin $(1 \mu \mathrm{g})$, Gentamicin $(1 \mu \mathrm{g})$, Ofloxacin $(5 \mu \mathrm{g})$ and Graxone $(30 \mu \mathrm{g})$. The suspension of the test organism in nutrient broth was matched with 0.5 McFarland turbidity standards to give a concentration of $1.5 \times 10^{8} \mathrm{CFU} / \mathrm{ml}$; while the inoculated plates were incubated at $35^{\circ} \mathrm{C}$ for $18-24$ hours. Multidrug resistance was defined in this study as resistance of Staph aureus to three or more antibiotics tested.

\subsection{Plasmid Curing of the MDR Staphylococcal Isolates}

A few colonies of antibiotic resistant Staph aureus were inoculated into $5 \mathrm{ml}$ of nutrient broth containing $0.1 \mathrm{mg} / \mathrm{ml}$ acridine orange and then placed in a shaker incubator at $37^{\circ} \mathrm{C}$ for $24 \mathrm{hrs}$. After incubation, the broth was aseptically swabbed onto Mueller-Hinton agar plate, and antibiotic susceptibility of the isolates was tested with the same panel of antibiotics used before the curing. Isolates susceptible to antibiotics to which they were previously resistant were taken to have borne plasmids which originally conferred resistance on them.

\section{Results}

Out of the 100 nasal specimens obtained from the asymptomatic persons, 32 (32\%) yielded Staph aureus. The rates of isolation from the volunteers and the rates in relation to gender are shown in Table 1. Health workers had a higher rate of isolation than food vendors, while isolation rate was higher in males (40\%) than in females $(24 \%)$.

The antimicrobial resistance profile of Staph aureus is given in Table 2. While all isolates were susceptible to Augmentin, there were relative differences in resistance shown to other antimicrobial agents used. Table 3 shows the pattern of multidrug resistance shown by nasal isolates of Staph aureus. 17 isolates displayed multidrug resistance. The different rates presented in Table 4 show the antibiotic susceptibility profile before and after curing the bacteria of any plasmids harbored by them.

The MDR pattern of Staph aureus isolates tested after plasmid curing is shown in Table 5. Out of the 17 (53\%) MDR isolates of Staph aureus, only 4 (23.5\%) remained MDR.

Table 1. Prevalence rate of Staph aureus among the subjects screened.

\begin{tabular}{llll}
\hline Subject & $\begin{array}{l}\text { Number of } \\
\text { Samples }\end{array}$ & $\begin{array}{l}\text { Staph aureus } \\
\text { isolates }\end{array}$ & $\begin{array}{l}\text { Percentage } \\
\text { isolation }\end{array}$ \\
\hline Food vendors & 50 & 14 & $28 \%$ \\
Health workers & 50 & 18 & $36 \%$ \\
Total & 100 & 32 & $32 \%$ \\
Gender & & & \\
Female & 50 & 12 & $24 \%$ \\
Male & 50 & 20 & $40 \%$ \\
Total & 100 & 32 & $32 \%$ \\
\hline
\end{tabular}


Table 2. Antimicrobial resistance profile of nasal isolates of Staph aureus.

\begin{tabular}{lllll}
\hline & & \multicolumn{2}{c}{$\begin{array}{c}\text { Overall } \\
\text { rate }\end{array}$} & \multicolumn{1}{c}{ resistance } \\
\cline { 3 - 4 } Antibiotics & Concentration & $\begin{array}{l}\text { Food } \\
\text { vendors (\%) } \\
\text { (N=14) }\end{array}$ & $\begin{array}{l}\text { Health } \\
\text { workers } \\
\text { (\%) } \mathbf{( N = 1 8 )}\end{array}$ & Total (\%) \\
\hline Amoxycillin & $25 \mu \mathrm{g}$ & $10(71.43)$ & $11(61.11)$ & $21(65.63)$ \\
Augmentin & $30 \mu \mathrm{g}$ & $0(0)$ & $0(0)$ & $0(0)$ \\
Ceftazidime & $30 \mu \mathrm{g}$ & $3(35.71)$ & $5(38.89)$ & $8(25)$ \\
Cefuroxime & $30 \mu \mathrm{g}$ & $2(21.43)$ & $3(33.3)$ & $5(15.63)$ \\
Oxacillin & $1 \mu \mathrm{g}$ & $7(50)$ & $9(50)$ & $16(50)$ \\
Gentamicin & $1 \mu \mathrm{g}$ & $2(28.57)$ & $1(38.89)$ & $3(9.38)$ \\
Ofloxacin & $5 \mu \mathrm{g}$ & $11(78.57)$ & $8(44.44)$ & $19(59.38)$ \\
Graxome & $30 \mu \mathrm{g}$ & $5(35.71)$ & $2(11.11)$ & $7(21.88)$ \\
\hline
\end{tabular}

Table 3. Multidrug resistance pattern of Staph aureus isolated from healthy subjects. $(N=32)$

\begin{tabular}{ll}
\hline $\begin{array}{l}\text { Number of antibiotics to which } \\
\text { there was resistance }\end{array}$ & $\begin{array}{l}\text { Number (\%) of resistant } \\
\text { isolates }\end{array}$ \\
\hline 1 & $2(6.25)$ \\
2 & $11(34.38)$ \\
3 & $7(21.88)$ \\
4 & $4(12.50)$ \\
5 & $1(3.13)$ \\
6 & $2(6.25)$ \\
7 & $3(9.38)$ \\
8 & $0(0.0)$ \\
Resistance to $\geq 3$ antibiotics & $17(53)$ \\
\hline
\end{tabular}

Table 4. Antibiotics susceptibility profile before and after plasmid curing.

\begin{tabular}{lllll}
\hline & $\begin{array}{l}\text { Number of } \\
\text { isolates } \\
\text { resistant } \\
\text { before } \\
\text { plasmid } \\
\text { curing }\end{array}$ & $\begin{array}{l}\text { Number of } \\
\text { isolates } \\
\text { sensitive } \\
\text { after } \\
\text { plasmid } \\
\text { curing }\end{array}$ & $\begin{array}{l}\text { \% } \\
\text { susceptibility } \\
\text { of Staph } \\
\text { aureus }\end{array}$ \\
\hline Amoxycillin $25 \mu \mathrm{g}$ & 21 & 21 & 100.0 \\
Augmentin $30 \mu \mathrm{g}$ & 0 & 0 & 0.0 \\
Ceftazidime $30 \mu \mathrm{g}$ & 8 & 3 & 37.5 \\
Cefuroxime $30 \mu \mathrm{g}$ & 5 & 2 & 40.0 \\
Oxacillin $\quad 1 \mu \mathrm{g}$ & 16 & 9 & 56.3 \\
Gentamicin $\quad 1 \mu \mathrm{g}$ & 3 & 3 & 100.0 \\
Ofloxacin $\quad 5 \mu \mathrm{g}$ & 19 & 14 & 73.7 \\
Graxome $\quad 30 \mu \mathrm{g}$ & 7 & 2 & 28.6 \\
\hline
\end{tabular}

Table 5. Multidrug resistance pattern of Staph aureus post plasmid-curing. $(N=17)$

\begin{tabular}{ll}
\hline $\begin{array}{l}\text { Number of antibiotics to which } \\
\text { there was resistance }\end{array}$ & $\begin{array}{l}\text { Number (\%) of resistant } \\
\text { isolates }\end{array}$ \\
\hline 1 & $4(23.53)$ \\
2 & $7(41.18)$ \\
3 & $2(11.77)$ \\
4 & $1(5.88)$ \\
5 & $1(5.88)$ \\
6 & $0(0.0)$ \\
7 & $0(0.0)$ \\
Resistance to $\geq 3$ antibiotics & $4(23.53)$ \\
\hline
\end{tabular}

\section{Discussion}

Staph aureus has remained one of the battled bacterial agents of infection in the African continent. Results of this study provide evidence on the recovery of Staph aureus from the nasal tracts of asymptomatic persons within and outside the hospital environment. In one study [15], nasal carriage of Staph aureus was associated with surgical infection in a hospital environment.

In the present study, $36 \%$ of those who harbored Staph aureus in their nostrils were hospital staff, made up of doctors, nurses and laboratory personnel. The usual close proximity to patients by this category of hospital workers could constitute a risk factor for the transmission of Staph aureus. Various reports have confirmed that nosocomial infection with Staph aureus is an important cause of morbidity and mortality among hospitalized patients in western European countries and the North American continent [16,17]. Ahmed et al. [15] have demonstrated possible cross colonization among staff, personnel and even cross infection from staff personnel to patients or from patients to patients.

Twenty-six percent (26\%) of volunteers in our study who harbored Staph aureus in their nasal tracts were food vendors. Nasal carriage is an important risk factor in outbreaks of food - borne diseases in which Staph aureus is incriminated. Teferi et al. [18] found that $20.5 \%$ of food handlers working in a University students' canteen were nasal carriers of Staph aureus. Nasal carriage rate as low as $0.77 \%$ has also been reported [19]. The source of the Staph aureus outbreak that affected 180 individuals in Brazil was also the food handlers carrying Staph aureus in their throats [20]. According to Bassyonni et al. [21], ecological differences of the study population may be responsible for the variations in nasal carriage rates.

Nasal carriers of this pathogen constitute a critical link between the pathogen and an infected individual, and poor personal hygiene can facilitate transmission of the organism from carriers to exposed food, thereby resulting to human infections when such contaminated foods are consumed, especially when toxigenic strains are involved. Common habits such as poking of nostrils with the finger and outbursts of sneezing are ready means of transmission of Staph aureus to food.

As also reported by $[22,23]$, the present study found no significant relationship $(\mathrm{P}>0.05)$ between gender and rate of nasal carriage of the pathogen. As much as $53 \%$ of the isolates displayed multidrug resistance to antibacterial agents tested. Multidrug resistance in this study was taken as resistance to 3 or more of the 8 antibacterial agents tested. Bacterial resistance of Staph aureus has become an intractable problem in medical circles; a mere 'headache' in the early 1940's, has gradually metastasized into a 'cancerous' problem in the $2010 \mathrm{~s}$ '!

Inappropriate use of antibiotics, their extensive use as growth enhancers in animal feed, the relative ease with which antimicrobial - resistant bacteria cross geographical 
barriers through regional and international travels, continue to add to this complex situation. According to Lowy [24] strains of Staph aureus resistant to methicillin, quinolones, and vancomycin now flourish within the human environment. Because of the possible risks of infection transmission by nasal carriage of Staph aureus, efforts have been directed to the elimination of carriage using topical antimicrobial [25].

With the exception of amoxicillin, gentamicin and augmentin, the resistance of Staph aureus to other antibiotics tested was plasmid-mediated (Table 4). Ibe et al. [26] have also shown that most cases of multiple-drug resistant strains of Staph aureus are due to plasmids.

Interestingly, the overall resistance of Staph aureus to Ofloxacin was $59.38 \%$ (Table 2) and the antibiotic susceptibility pattern before and after plasmid curing of the organism, showed a susceptibility of $73.7 \%$ to Ofloxacin, i.e., 5 isolates out of the 19 isolates tested still remained resistant after plasmid curing. The broad - spectrum antimicrobial nature of the quinolones made them a welcome choice for treating bacterial infections in the 1980s. However, subsequent widespread use of quinolones and fluoroquinolones has led to a steady global increase in resistance, mediated via spontaneous chromosomal gene mutation in the target of the antibiotic, topoisomerase IV or DNA gyrase, or by the induction of a multidrug efflux pump, as well as plasmid - mediated resistance. The first plasmid-mediated quinolone resistance gene, qnrAl, was detected in 1998[(27].

The use of quinolones to treat other bacterial pathogens could result, in the subjects colonized with Staph aureus, to exposure to subtherapeutic antibiotic concentrations and are therefore at risk of becoming colonized with resistant mutants [28]. These resident, resistant strains could serve as sources of subsequent infections in the environment.

The nasal isolates of Staph aureus showed a high resistance $(65.3 \%)$ to amoxicillin, a $\beta$-lactam antibiotic. This, probably, is a result of the degrading effect of $\beta$ lactamase on the antibiotic molecule, rendering it ineffective for treating staphylococcal infections. Also, inappropriate use of this antibiotic in the community resulting from lack of monitoring the availability of this antibiotic has obviously led to its misuse with a resultant exertion of antibiotic selective pressure, resulting in the spread of the more resistant strains. All isolates were susceptible to augmentin; probably due to the presence of clauvilanic acid (a competitive inhibitor of $\beta$ - lactamase) that restores the antimicrobial activity of amoxicillin against Staph aureus, a known $\beta$-lactamase secreting bacterium. The resistance to cefuroxime and ceftazidine was low, possibly due to the bactericidal nature of these antibiotics on the isolates. In addition, cefuroxime, a second generation cephalosporin, is resistant to $\beta$ lactamase. The need for a doctor's prescription and the high cost of buying the injectable form of this antibiotic limit its abuse.

\section{Conclusion}

Significantly, this study has shown that hospital workers and food vendors can serve as healthy nasal carriers of Staph aureus, and the resistance of some of the isolates was plasmid-mediated. The use of nose masks by food handlers, use of hand gloves and face masks, and regular hand washing by doctors and nurses, before and after attending to patients as well as periodical medical examination of employees in food industries and health institutions, could help to prevent spread of resistant strains of Staph aureus. In general, strict infection control measures are required, in order to protect those at possible risk of infection.

\section{Acknowledgements}

We express our gratitude to those participants from whom specimens were taken for this study, and the Medical Directors of the various health facilities contacted.

\section{References}

[1] Kuehnert, M. J., D. Kruszon-Moran, H. A. Hill, G. McQuillan, S. K. McAllister, G. Fosheim, L. K. McDougal, J. Chaitram, B. Jensen, S.K. Fridkin, G. Killgore, and F. C. Tenover. 2006. Prevalence of Staphylococcus aureus Nasal Colonization in the United States, 2001-2002. The Journal of Infectious Diseases. 193:172-9.

[2] Ellis, M., A. Serreli, P. Colque-Navarro, U. Hedstrom, A., Chacko, E. Siemkowicz, and R. Möllby. 2003. Role of staphylococcal enterotoxin A in a fatal case of endocarditis. J. Med. Microbiol . 52 (2) 109-112. Doi: 10.1099/jmm.0.05003-0

[3] Von Eiff, C., K. Becker, K. Machka, H. Stammer, and G. Peters. 2001. Nasal carriage as a source of Staphylococcus aureus bacteremia. Study Group. N. Engl. J. Med. 344(1):11-6.

[4] Olonitola, O. S., H. I. Inabo , B. O. Olayinka, and I. D. Bugo. 2007. Nasal carriage of methicillin-resistant Staphylococcus aureus by primary school pupils in a university staff school, Zaria, Nigeria. International Journal of Biological \& Chemical Sciences. 1 (1): pp. 71-75. DOI: http://dx.doi.org/10.4314\%2Fijbcs.v1i1.39701

[5] Gorwitz, R.J., D. Kruszon-Moran, S. K. McAllister, G. McQuillan, L.K. McDougal, G. E. Fosheim, B.J. Jensen, G. Killgore, F. C. Tenover, and M.J. Kuehnert. 2008. Changes in the Prevalence of Nasal Colonization with Staphylococcus aureus in the United States, 2001-2004. The Journal of Infectious Diseases. 197:1226 -34 DOI: $10.1086 / 533494$

[6] Onanuga, A., and T.C. Temedie. 2011. Nasal carriage of multi-drug resistant Staphylococcus aureus in healthy inhabitants of Amassoma in Niger Delta region of Nigeria. African Health Sciences. 11(2): $176-181$.

[7] Guido, A.G., T. Lingscheid, S. Tobudic, and H. Burgmann. 2012. Low nasal carriage of drug-resistant bacteria among medical students in Vienna. GMS Krankenhhyg Interdiszip. 7(1):doi: 10.3205/dgkh000188 
[8] Kluytmans, J., A. Van Belkum, and H. Verbrugh. 1997. Nasal carriage of Staphylococcus aureus: epidemiology, underlying mechanisms, and associated risks. Clin Micro Rev. 10:505-520.

[9] Zanger, P., D. Nurjadi, B. Vath, and P.G. Kremsner. 2011. Persistent nasal carriage of Staphylococcus aureus is associated with deficient induction of human beta-defensin 3 after sterile wounding of healthy skin in vivo. Infect Immun. 79(7): 2658-62.

[10] Uwazuoke, J.C., and L. E. Aririatu. 2004. A survey of antibiotic resistant Staphylococcus aureus strains from clinical sources in Owerri. J. Appl. Sci. Environ. Managt. $8(1): 67-68$.

[11] Montefiore, D., V.O. Rotimi, and F.A. Adeyemi-Doro. 1989. The problem of bacterial resistance to antibiotics among strains isolated from hospital patients in Lagos and Ibadan, Nigeria. J. Antimicrob. Chemother.23(4):641-51.

[12] Kloss, W.E., A. Topley, and J. Wilson, 1998. Staphylococcus in microbiology and microbial infections. London, Edward Arnold Vol 2. $9^{\text {th }}$ edition pp 602-611.

[13] Tenover, F.C., and R.C.J. Moellering. 2007. The rationale for revising the clinical and laboratory standards institute vancomycin minimal inhibitory concentration interpretative criteria for Staphylococcus aureus. Clin Infect Dis. 44:12081215 .

[14] Clinical and Laboratory Standards Institute. 2010. Performance standard for antimicrobial susceptibility testing. Approved standard M100-S20. 30(1).National Committee for Clinical Laboratory Standards, Wayne, PA. USA.

[15] Ahmed, A.O.A., A. Van Belkum, A.H. Fahal, A.E.A. Elnor, A.M. Abougroun, and M.F.Q. Vandenbergh.1998. Nasal carriage of Staphylococcus aureus and epidemiology of surgical-site infections in a Sudanese university hospital. J. Clin. Microbiol. 36(12): 3614-3618.

[16] Horan, T. C., R. P. Gaynes, W. J. Martone, W. R. Jarvis, and T. G. Emori. 1992. CDC definitions of nosocomial surgical site infections 1992: a modification of CDC definitions of surgical wound infections. Infect. Control Hosp. Epidemiol. 17:780-785.

[17] Dixon, R. E. 1995. Cost of nosocomial infections and benefits of infection control programs, In: R. P. Wenzel (ed.), Prevention and control of nosocomial infections. The Williams and Wilkins Co., Baltimore, Md. p. 19-25.

[18] Teferi, M.D., M.T. Wube, F.M. Yehuala, and Z.T., Mehari. 2012. Survey of nasal carriage of Staphylococcus aureus and intestinal parasites among food handlers working at Gondar University, Northwest Ethiopia. BMC Public Health, 12 (1): 837.
[19] Gunduz, T., M.E. Limoncu, S. Cumen, A. Ari, S. Etiz, and Z. Tay. 2008. Prevalence of intestinal parasites and nasal carriage of Staphylococcus aureus among food handlers in Manisa, Turkey. J. Environ. Health. 18(5):230- 235.

[20] Colombari, V., Mayer, M.D.B., Laicini, Z.M., Mamizuka, E., Franco, B.D.G.M., M.T. Destro, and M. Landgraf. 2007. Foodborne outbreak caused by Staphylococcus aureus: phenotypic and genotypic characterization of strains of food and human sources. Journal of Food Protection. 70 (2): 489493.

[21] Bassyouni, R.H., N. El-Sherbiny, E.H Hefzy, and A-A. Wegdan. 2012. Perception of food safety and prevalence of Staphylococcus aureus and Salmonella species carriers among Fayoum University food handlers. Life Sci. J. 9(4):2934 -2940.

[22] Khorvash, F., F. Abdi, B., N. H. Fattahi, K.H. Hasanzadeh, and T. Narimani. 2012. Nasal carriage of Staphylococcus aureus: Frequency and antibiotic resistance in healthy adults. J. Res. Med. Sci. 17(Spec 2): S229-S232.

[23] Ghasemian, R., N. Najafi, A. Makhlough, and M. Khademloo. 2010. Frequency of nasal carriage of Staphylococcus aureus and its antimicrobial resistance pattern in patients on hemodailysis. Iran J Kidney Dis. 4(3): 218-22.

[24] Lowy, F.D. 2003. Antimicrobial resistance: the example of Staph aureus. The Journal of Clinical Investigation 111(9):1265-1273.

[25] Perl, T.M., Cullen, J.J., Wenzel, R.P., Zimmerman, M.B., Pfaller, M.A., Sheppard, D., J.Trombley, P.P. French, and L.A. Herwaldt. 2002. Intranasal mupirocin to prevent postoperative Staphylococcus aureus infections. N. Engl. J. Med. 346(24): 1871-1877. doi: 10.1056/NEJMoa003069

[26] Ibe, C., R. A. Onyeagba, and S. C. Ugochukwu. 2014. Antibiotic resistance Patterns and Plasmid profiles of methicillin resistant Staphylococcus aureus isolates from human samples. British Microbiology Research Journal. 4(2): 185-194.

[27] Guan, X., X. Xue, Y. Liu, J. Wang, Y. Wang, J. Wang, K. Wang, H. Jiang, L. Zhang, B. Yang, N., and L. Pan. 2013. Plasmid-mediated quinolone resistance - current knowledge and future. Journal of International Medical Research. 41: 20-30. DOI: $10.1177 / 0300060513475965$

[28] Hooper, D.C. 2002. Fluoroquinolone resistance among Gram-positivecocci. Lancet Infect. Dis. 2:530-538. 